\title{
ECONOMICS OF HEALTH CARE FINANCING: THE VISIBLE HAND
}




\section{ECONOMIC ISSUES IN HEALTH CARE}

General editors

Professor Gavin Mooney

Dr Alistair McGuire

Department of Community Medicine

Department of Economics

Westmead Hospital

Westmead, NSW 2145

Australia

City University

Nottingham Square

London ECIV OHB

The Challenges of Medical Practice Variations

Edited by Tavs Folmer Andersen and Gavin Mooney (1990)

Competition in Health Care: Reforming the NHS

Edited by A. J. Culyer, Alan Maynard and John Posnett (1990)

Strategies for Health Care Finance in Developing Countries

By Guy Carrin with Marc Vereecke (1992)

Private Exchange and Public Interest

By John Forbes (1992)

Just Managing-Power and Culture in the NHS

By Stephen Harrison, David J. Hunter and Gordon Marnoch (1992)

Economics of Health Care Financing: The Visible Hand

By Cam Donaldson and Karen Gerard (1992)

Rationing and Rationality in the National Health Service Edited by Stephen J. Frankel and R. R. West (1993)

Health Status Measurement: A Perspective on Change

By Richard Brooks (1995) 


\section{ECONOMICS OF HEALTH CARE FINANCING: THE VISIBLE HAND}

\section{Cam Donaldson}

Health Economics Research Unit

Department of Public Health

University of Aberdeen

and

\section{Karen Gerard}

Division of Epidemiology and Public Health

University of Newcastle-upon-Tyne

and formerly Health Economics Research Unit

University of Aberdeen

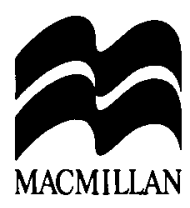




\section{(C) Cam Donaldson and Karen Gerard 1993}

All rights reserved. No reproduction, copy or transmission of this publication may be made without written permission.

No paragraph of this publication may be reproduced, copied or transmitted save with written permission or in accordance with the provisions of the Copyright, Designs and Patents Act 1988, or under the terms of any licence permitting limited copying issued by the Copyright Licensing Agency, 90 Tottenham Court Road, London W1P 9HE.

Any person who does any unauthorised act in relation to this publication may be liable to criminal prosecution and civil claims for damages.

First published 1993 by

THE MACMILLAN PRESS LTD

Houndmills, Basingstoke, Hampshire RG21 2XS

and London

Companies and representatives

throughout the world

ISBN 978-0-333-53870-8

ISBN 978-1-349-22512-5 (eBook)

DOI $10.1007 / 978-1-349-22512-5$

A catalogue record for this book is available from the British Library.

$\begin{array}{llllll}11 & 10 & 9 & 8 & 7 & 6\end{array}$

$\begin{array}{lllllll}03 & 02 & 01 & 00 & 99 & 98 & 97\end{array}$ 


\section{Contents}

Acknowledgements

\section{PART 1 MARKETS AND MARKET FAILURE IN HEALTH}

CARE

1 Health Care Financing Reforms: Moving into the 1990s 3 Introduction 3

The changing world of health care financing 4 Western Europe 4

Eastern Europe $\quad 5$

North America $\quad 6$

Latin America $\quad 7$

Australasia $\quad 8$

Less-developed Countries (LDCs) 9

Outline of the book $\quad 10$

2 Markets and Health Care 12

Introduction $\quad 12$

What is a market and how does it work? 13

Markets: the panacea for health care ills? 19

The crucial assumptions $\quad 20$

Certainty 21

No externalities $\quad 21$

Perfect knowledge $\quad 22$

Consumers act free of self-interested 'advice' from doctors 23

Numerous, small producers with no market power 23

Consumer is sovereign? $\quad 24$

$\begin{array}{ll}\text { Conclusions } & 25\end{array}$

3 Market Failure in Health Care 26

Introduction $\quad 26$

Risk, uncertainty and the failure of private health care

insurance 28

Uncertainty and the demand for insurance 28

Diseconomies of small scale $\quad 29$ 
Moral hazard $\quad 31$

Adverse selection $\quad 35$

$\begin{array}{ll}\text { Externalities } & 37\end{array}$

Licensure and asymmetry of information 41

The need for a profession $\quad 41$

The problem of asymmetry $\quad 42$

Are doctors perfect agents? $\quad 43$

Relevance of economics to government intervention 45

$\begin{array}{ll}\text { Conclusions } & 47\end{array}$

PART 2 HEALTH CARE SYSTEMS AND THEIR OBJECTIVES

4 Alternatives for Funding Health Care 51

Introduction 51

Public-private mix in finance and provision 52

Rewarding the providers 54

Private health care insurance 55

Preferred provider organisations (PPOs) 57

Direct tax system $\quad 58$

Public health care insurance $\quad 61$

Health maintenance organisations (HMOs) 63

Other financing mechanisms $\quad 64$

$\begin{array}{ll}\text { Conclusions } & 65\end{array}$

5 Economic Objectives of Health Care 68

$\begin{array}{ll}\text { Introduction } & 68\end{array}$

Efficiency $\quad 68$

Effectiveness $\quad 69$

Operational efficiency $\quad 69$

Allocative efficiency $\quad 70$

Equity $\quad 72$

Confronting the confusion: what do we mean by equity? 72

Equity and externalities $\quad 72$

Equity or equality?

Equity of health care or health?

Horizontal equity $\quad 74$

Vertical equity $\quad 76$

Muddying the waters: equity policies and pronouncements 78

The economics and philosophy interface - theories of equity 81

Towards some operational equity goals $\quad 82$

Interaction between equity and efficiency 83

Conclusions $\quad 83$ 
6 Countering Consumer Moral Hazard $\quad 87$

$\begin{array}{ll}\text { Introduction } & 87\end{array}$

Policy responses to consumer moral hazard $\quad 88$

Evidence on countering consumer moral hazard $\quad 89$

Copayments $\quad 89$

Fixed, periodic, per-capita payment $\quad 94$

Preferred provider organisations $\quad 96$

Fixed indemnity $\quad 97$

Non-price rationing $\quad 98$

Conclusions $\quad 99$

7 Countering Doctor Moral Hazard 101

$\begin{array}{ll}\text { Introduction } & 101\end{array}$

Methods of paying doctors 102

Fee for service: does supplier inducement really exist? $\quad 103$

Supplier-induced demand: evidence and explanations 103

$\begin{array}{ll}\text { Intervening to set fees } & 107\end{array}$

Alternatives to fee for service 108

Salaries 108

Special payments for 'good practice' 109

Capitation 110

Clinicians as budget holders $\quad 112$

Government regulation 113

$\begin{array}{ll}\text { Conclusions } & 114\end{array}$

8 Countering Moral Hazard in the Hospital Sector 116

$\begin{array}{ll}\text { Introduction } & 116\end{array}$

$\begin{array}{ll}\text { Theoretical perspectives } & 117\end{array}$

Methods of reimbursing hospitals: a case of minding our P's and $Q$ 's?

Retrospective reimbursement at full cost (minding neither $P_{i}$ nor

$\left.Q_{i}\right)$

Prospective reimbursement (minding $P_{i}, P_{i} Q_{i}$ or $\sum P_{i} Q_{i}$ ) 121

Competition (minding $P_{i}, Q_{i}$ or $P_{i}$ and $Q_{i}$ together) 123

Empirical evidence on reimbursing hospitals 125

Retrospective versus prospective reimbursement 125

Competition 135

Does ownership make a difference? 136

Towards a solution: back to budgeting? 138

Conclusions 
9 Achieving Equity 143

Introduction $\quad 143$

The role of government in health care financing 144

Evidence on vertical equity 145

Income and health care contributions $\quad 145$

Charges and community financing in LDCs 148

Evidence on equity as access $\quad 150$

Some brief international comparisons $\quad 150$

USA: No explicit equity objective 153

Canada: Objective - equality of utilisation 157

UK: Objective - equal access for equal need $\quad 158$

Finland: Objective - equality of geographical utilisation $\quad 161$

Conclusions

PART 4 FUTURE CHALLENGES

10 Future Considerations: Setting the Health Care Budget 167

$\begin{array}{ll}\text { Introduction } & 167\end{array}$

What are the determinants of total health care spending? 168

What is the appropriate level of spending? 173

Where do we go from here? Relating broad inputs to broad $\begin{array}{ll}\text { outputs } & 174\end{array}$

Where do we go from here? Economic evaluation 176

Where do we go from here? Other sectors' contributions to health

Conclusions

11 Health Care Financing Reforms: Challenges for the 1990s 183

$\begin{array}{ll}\text { Introduction } & 183\end{array}$

The contribution of economic theory 184

Empirical findings - how health services should be financed 185

The financial intermediary $\quad 186$

Financing and the supply side $\quad 186$

Financing and the demand side 188

Determining the size of the budget 189

$\begin{array}{ll}\text { Conclusions } & 189\end{array}$

$\begin{array}{ll}\text { Notes } & 190\end{array}$

$\begin{array}{ll}\text { References } & 193\end{array}$

$\begin{array}{ll}\text { Subject Index } & 211\end{array}$

$\begin{array}{ll}\text { Author Index } & 214\end{array}$ 


\section{Acknowledgements}

There are many people to thank for their help in producing this book.

First, we would like to thank the series editors, Gavin Mooney and Ali McGuire, for helping us through the final stages of the production process.

We would also like to thank our colleagues in various institutions; many of our ideas were formed and much writing was done while at these places. Therefore, we are grateful to our colleagues at the Department of Public Health at the University of Sydney, at the Centre for Health Economics Research and Evaluation at Westmead Hospital in Sydney, and at the Centre for Health Economics at the University of York. Special help at each of these sites was provided by Monika Bhatia, Jackie Dettman, Julie Glanville, Alan Maynard and Owen O'Donnell.

The following people provided us with valuable information on particular countries: Tamas Angelus (Hungary), Toni Ashton (New Zealand), Joan Artells (Spain), Ivar Sønbo Kristiansen (Norway), Ken Lee (USSR), Marian Matulewicz (Poland) and Frans Rutten (The Netherlands).

Thanks are also due to our colleagues in the Health Economics Research Unit: in particular Doreen Adams, Anne Bews and Shelley Farrar.

Finally, this book could not have been written without the support and inspiration provided by Tony Culyer of the University of York, and by Gavin Mooney. Much of the work presented here originated from a project on health care financing, carried out with the Institute for Health Services Management under Tony's supervision. All that Gavin did was to make us believe we could write a book in the first place! 